\title{
On Practice of the Citizen Education in Social Fields in the Early Years of the United States
}

\author{
Heng $\mathrm{Wu}$ \\ School of Marxism Studies, Yangzhou University, Yangzhou, 225009, China \\ ydwuheng@126.com
}

\begin{abstract}
In addition to the school education way, the citizen education about the early years in social fields in the United States is carried out by party politics, religion and social group activities. The political activities of political parties and elections activities gradually become an important way to carry out citizen education. American civil religion based on the spread of patriotism and national supreme values and advocates greatly inspired the national cohesion and cultivated the American national consciousness and national consciousness. The political parties and social organizations have close relations, they are on the formation and spread of public opinion, to express party politics played a huge role.
\end{abstract}

Keywords-citizen education; political activities; religious activities; social group activities

\section{INTRODUCTION}

In the early days after foundation, civic education not only did in the way of school education, and did in all spheres of society, through a variety of social activities, in various forms to carry out. Can say, the United States in the early days after foundation of civic education is a kind of open, through the broad integrated way implemented, is not limited to the narrow scope of school education, Webster open education idea at the time of the civil education practice to reflect deeply. In addition to the school education, at the beginning of the founding of the citizen education also by party politics, religion and social group activities are all way to implement.

\section{CITIZEN EDUCATION PRACTICE IN THE POLITICAL ACTIVITIES}

Although Jefferson, rush the founding fathers in the late 18th century is put forward to establish the public education system in order to realize the popularity of education, but in fact by Horace Mann in the $1830 \mathrm{~s}$ and other public education advocates a huge public education campaign, and after 30 years of development, until the $1860 \mathrm{~s}$, American public education system was basically established. So, at the beginning of the founding, the public education system is imperfect determines the school education at that time also can't become a wide range to make most of the American people can accept citizen education means, only depends on school education to promote civic education, role is very limited, so the citizen education rely on other ways to expand his scope of implementation, and party politics is an important way of early American citizen education. The United States is the most typical of the contemporary world of party politics. It can be said that the American political parties from the date of birth, became a citizen democracy is an important way of education. In fact, in the United States at the beginning of the founding, the founding fathers of the United States are extremely opposition party politics and administration in Washington, there is no political parties in America. But as the change of political situation, political top appeared headed by Hamilton federalists and headed by Thomas Jefferson "the federalists. Jefferson's supporters after the Democratic Party is established in 1791, in 1794 changed its name to the republican (democratic republican), Jefferson said republican. In 1801, Jefferson rely on republican victory over John Adams was elected President of the United States; the two-party system began to appear. Since then, after multiple differentiation and combination to the eve of the civil war, became the two major political parties in American politics, republicans and Democrats. During this period, as the democratic political development needs within political parties and their political activities, to the cultivation of the awareness of citizens and political participation provides a good opportunity, has injected new vitality to the development of civic education.

The end of the 18th century in the early 19th century, the party political activity is increasingly frequent, rich. Because, the competition of political parties and voters rights expands, decided to win in the election, the party can't only by the parliament struggle, and must seek power in society in order to gain more support from the voters. For this purpose, the parties will use a variety of media to the public before an election provides plenty of political information, make the public understanding of the basic information of the candidates, political views and political agenda, the U.S. election, the basic process and the basic principles of the American political system, to generate citizens to actively participate in national political life and attract more voters support their party candidate. Party politics, on the other hand, also make the voters get to know, as an ordinary citizen, only by parties to the huge political machines will run their ideas and wishes into the political system, which are recognized by the state and the legal safeguard, to gain more democratic rights. Because, "hold vote of man is the master of mastering the situation... is opportunity, education, civil competition, from the regime and the opportunity to get ahead."[1] This makes the voters have more enthusiasm and spare more time to care about politics, pay attention to the election, to improve their own ability to participate. This to a certain extent also strengthened the general citizens' political participation of the subjective desire. 


\section{CitIZEN EDUCATION PRACTICE IN THE RELIGIOUS ACTIVITIES}

Religion is an important force in American public life. The influence of religion on American politics is huge, religious ruling class by the United States as to instill the concept of values and political tool. In America, religion has very strong political, religious people also pay close attention to the development of national politics, and actively participate in political activities. Religion is the United States to carry out civic education in the early days after foundation of another important way.

In the late $1790 \mathrm{~s}$, the United States for the second time "great awakening" of religion, the religious revival began the second time, the time until the late $1840 \mathrm{~s}$. In the religious revival movement, American evangelicals are the most active, the influence on society. Evangelical protestant religion itself is a kind of religion. Especially the second great awakening will no longer religious revival itself as the only goal, but emphasizes the necessity of religious revival to ensure that the American social system. Therefore, the content of the priest preached sermons is full of patriotism and political content. Priests the patriotism and the protestant doctrine perfectly blend together, and make it widely as a kind of ideal to instill in the United States, to cultivate patriotic, law-abiding citizens and consolidate the new republic played a major role. In addition, it is worth noting that the church in the process of immigration Americanized also plays a key role. In many immigrant communities, language, ethnic and religious sacrament and become the core of a traditional, family, church, school, newspapers and charity organization actively push and promote together, and the church as the spiritual leader and organization hub. For example, when New York Catholic Irish Catholic, Catholic in Italy and Germany both want to try my best to keep its unique language and culture and their special way of worship, but in the end because the Irish priest in New York the intention of the dominant and the other two failed to materialize.

Evangelical characteristics and its status in American society make it a significant force in American political life. Evangelical played a significant role in promoting the social reform. They formed a variety of association, the religious belief and education, women, and political problems such as the anti-slavery together. They believe that their own responsibilities, bear the responsibility of Christians not only, also undertake the role of citizen, "as part of the duty to god, Christians must take responsibility for the country, away from the political will make the country fell into the hands of the tyrant."[2] Theologians and missionaries in the country's education is very concerned about, their writing, on how to put the people of the United States to develop into the qualified citizens of the republic of arduous exploration, among them have produced a batch of outstanding citizen education theorists, such as, Stan's tome, 1. Smith, Horace Bushnell, Lyman Beecher, etc. Their exploration of citizen education theory to the United States has produced important influences on the development of civic education in the early days after foundation.
At the beginning of the founding, the United States use religion to carry out civic education, to a great extent, is actually civil religion as the carrier. Although the United States civil religion in the sixties of the 20th century began to appear in theory, but it has a long development process, it in the colonial period began to sprout, development in social change constantly, improve and mature. Civil Religion (Civil Religion) a word comes from Rousseau's "social contract theory". Rousseau illustrates the principles of civil religion, such as the existence of god, the belief in an afterlife, to reward good punishing evil, he proposed the theory of civil religion the intention to lessen the reformation in Europe after the sharp conflict between the religious and political groups, form a harmonious relationship between church and state. In the 1950 s American scholar Hector's (Will Herzberg) put forward American religiosity and national character has a close relationship between the United States is a kind of American common identity has both religious and secular nature of religious ethics value, in this kind of religious, national life and national value be sanctified and religious. In 1967, American scholar Robert Bella in the context of the American civil religion "clearly puts forward the concept of" civil religion ", "he thought," civil religion explained from the perspective of transcendence from the history of the United States produced by a whole set of religious beliefs, symbols, and ceremonies, a religious symbol and faith the main body, has become a central force in American life."[3] Civil religion is, as it were, contains various symbolic system of symbols and themes, mainly embodied in a variety of festivals and ceremonies, such as memorial day and his inauguration ceremony.

Citizens religious ideas are European immigrants in the United States, originated in the colonial period, and obtain further development in the early days after foundation of people in the United States. American civil religion by the profound influence of the Puritan and deism, which is fully embodied in early American history: before he was the first European settlers to North America to sign the "mayflower convention", voters believe they are god, will be completed under the guidance of god, the cause of god, god will always bless them; In the United States after independence, support the principle of separation of church and state, opposed to create state religion. Wrote the declaration of independence is the beginning of the "we think the following these truths to be self-evident: that all men are created equal, the creator gave them certain inalienable rights", namely, Americans believe themselves to enter into a contract with god, to accept god's instructions, to achieve national independence. At the beginning of the America's founding, the United States civil religion got further development. The early founding of the people's inaugural speech of the President of the United States also with a strong religious color has repeatedly referred to god. In America at the beginning of the founding of the religious revival movement, an evangelical association, in the heart of the missionary activities teaching and education, women, and political problems such as the anti-slavery together, advocating Christians bear civil responsibility, loyalty to the country, the maintenance of democratic politics, essentially is the embodiment of the civil religion. 
Civil religion although have religious, but its political indeed far stronger than religious, its purpose is through people's religious emotion expressing political beliefs, for a country's political and service. Undoubtedly, the citizen religion is a kind of effective means of citizen education. American citizen religion is a belief system with transcendental significance; it is the political ideology and the concept of American values, special expression, basically in order to maintain the democracy republican system in the United States.

\section{CITIZEN EDUCATION PRACTICE IN THE COMMUNITY ACTIVITIES}

In the United States in the early days after foundation, due to the establishment of a democratic republic, the people's rights consciousness growing phenomenon more and more get people's recognition of association, social organizations have developed quickly. There are 114 in the $1880 \mathrm{~s}$, is only Massachusetts social organizations, in the $1820 \mathrm{~s}$, rose to 852 . These organizations to actively participate in social reform, focus on national politics, they are committed to the international peace, the feminist movement, education, law, alcohol and the abolitionist, among all kinds of things. As Connecticut republican association says the aim is to: "to support local and across the United States constitution and laws, their lives, is diligently; exercise of constitutional liberty of speech and debate, perpetuate human rights equality; promote political knowledge, to stimulate the war of independence of the republic spirit."[4] And the association of concentrate on education, such as "New York democratic society" to promote ignorance is "the deadly enemy of freedom", claimed that the aim is to "expand the role of the useful knowledge". [5] Association of these very active, they often meeting, organize the masses assembly, a procession or a memorial rally and political speeches, they through communications report, a lot of propaganda materials, brochures, newspapers and other propaganda their views to the public. These community groups had a great impact on public opinion; make the public policy to learn more about the country and all kinds of social hot issues. Aroused the public social organizations of these activities to national public issues of interest, such as politics, social reform, improve the public political participation and the desire and ability of social management, public virtually suffered a extensive and profound political education. Community organizing is an important way to the United States in the early days after foundation of citizen education.

These political parties and social organizations have close relations, they are on the formation and spread of public opinion, to express party politics played a huge role. In the late $1790 \mathrm{~s}$, the United States appeared a batch of philanthropy, mutual funds and political education in one of the new type of political association. Due to the need of party competition, the support of different political parties association and also committed to the party politics of party newspaper, the conflict of opposing views from now on become the basic elements of the public affairs. Then, a new form of education appeared on the stage in public affairs. In this stage, some people or promoting its claims, enumerate examples, or orders, others attend, or thinking, or to participate in the debate. This is a kind of is the result of conflict and the impact of education. Party competition and conflict of opposing views is to make people's benefit, the result of the enlightenment. Non familial social organizations should not be in the family circle transmission technology, attitudes and values on to the club members, the increase of social organizations to expand and the public more and more involved in public affairs, inevitably increases the chance to receive education to the public.

\section{REFERENCES}

[1] William Gillette. The Right to Vote: Politics and the Passage of the Fifteenth Amendment. Baltimore: Johns Hopkins University Press, pp.87-88, 1965.

[2] Mark A. Noll. God and Mammon: Protestants, Money, and the Market, 1790-1860. Oxford University Press, pp.56, 2002.

[3] Beyond Belief: Essays on Religion in a Post-traditional World. New York: Harper\& Row, 1970.

[4] Lawrence A. Cremin. American Education: The National Experience, 1783-1876. Beijing normal University Press, pp. 217,333. 